\title{
EFISIENSI PEMASARAN KACANG HIJAU (Vigna radiata, L.) DI KABUPATEN INDRAMAYU
}

\author{
Reynaldi $^{1}$, Juri Juswadi ${ }^{2}$, Neneng Sri Mulyati ${ }^{3}$ \\ Program Studi Agribisnis, Fakultas Pertanian, Universitas Wiralodra \\ E-mail : Reynaldie555@gmail.com¹, yuswadi_yuri@yahoo.co.id ${ }^{2}$, nenengsrimulyati44@gmail.com
}

\begin{abstract}
ABSTRAK
Tujuan penelitian ini adalah mengetahui besarnya nilai elastisitas transmisi harga dan efisiensi pemasaran kacang hijau di Kabupaten Indramayu tahun 2013-2017. Penelitian ini dilakukan dengan menggunakan metode deskriptif. Penelitian ini menggunakan model ekonometrika dengan menggunakan data time-series harga bulanan produsen dan harga bulanan konsumen dari bulan Januari 2013 sampai dengan bulan Desember 2017. Berdasarkan hasil penelitian menunjukkan bahwa besarnya nilai elastisitas transmisi harga sebesar 0,934 artinya Et kurang dari 1, perubahan harga sebesar $1 \%$ di tingkat konsumen akan mengakibatkan perubahan harga di tingkat produsen sebesar 0,934\%. Sehingga dapat disimpulkan bahwa pemasaran kacang hijau di Kabupaten Indramayu tidak efisien.
\end{abstract}

Kata kunci: Efisiensi, Elastisitas, Harga, Pemasaran.

\section{PENDAHULUAN}

Kabupaten Indramayu merupakan salah satu wilayah yang memproduksi kacang hijau. Hal yang mendukung lahan pertanian di Kabupaten Indramayu cocok untuk ditanami kacang hijau yaitu iklim, tekstur tanah (liat berpasir) dan cuaca yang baik untuk pertumbuhan kacang hijau apalagi ditanam saat musim gadu (kemarau). Kabupaten Indramayu memiliki luas 209.942 Ha yang terdiri dari $116.805 \mathrm{Ha}(55,64 \%)$ tanah sawah dan 93,137 Ha (44,36\%) tanah kering. Tanah sawah terdiri dari sawah irigasi sebesar $93.401 \mathrm{Ha}(79,96 \%)$ dan sawah tadah hujan sebesar 23.404 (20,04\%) (BPS Kabupaten Indramayu 2014). Luas panen, produksi, dan produktivitas kacang hijau di Kabupaten Indramayu dapat dilihat pada Tabel 1. Tabel tersebut menunjukkan bahwa produktivitas kacang hijau di Kabupaten Indramayu dari tahun 2013 sampai dengan tahun 2017 mengalami fluktuasi. Produktivitas tertinggi terjadi pada tahun 2014 dan terendah tahun 2016.

Tabel 1. Jumlah Luas Panen, Produksi, dan Produktivitas Kacang Hijau di Kabupaten Indramayu Tahun 2013-2017.

\begin{tabular}{ccccr}
\hline No & Tahun & Luas Panen (Ha) & Produksi (Kw) & $\begin{array}{c}\text { Produktivitas } \\
(\mathbf{K w / H a})\end{array}$ \\
\hline 1 & 2013 & 410 & 423,84 & 10,34 \\
2 & 2014 & 1.448 & $4.445,80$ & 30,70 \\
3 & 2015 & 604 & 696,14 & 11,53 \\
4 & 2016 & 386 & 334,20 & 8,66 \\
5 & 2017 & 1.049 & $1.235,36$ & 11,79 \\
\hline & Rata-rata & 779,4 & $1.427,068$ & 14,602 \\
\hline
\end{tabular}

Sumber : Badan Pusat Statistik Kabupaten Indramayu (2014-2018).

Saat ini terjadi perubahan orientasi dalam kegiatan pertanian, dari pertanian yang berorientasi kepada produksi menuju pertanian yang berorientasi pasar. Artinya dalam kegiatan usahatani sebelum menentukan produksi komoditas tertentu perlu melihat kebutuhan konsumen sehingga kegiatan pemasaran menjadi efisien. Efisiensi pemasaran adalah seberapa besar pengorbanan yang harus dikeluarkan dalam kegiatan pemasaran menunjang hasil yang bisa didapatkan dari kegiatan pemasaran tersebut. Perubahan orientasi tersebut sampai saat ini masih menemui berbagai kendala 
salah satunya adalah posisi tawar (bergaining power) petani yang rendah yang diakibatkan dikuasainya kendali pemasaran oleh pelaku pemasaran (Direktorat Jenderal Pemasaran, 2006).

Berdasarkan hubungan informasi pasar yang dianalisis, tingkat keterkaitan hubungan suatu lembaga pemasaran dengan lembaga pemasaran lainnya dalam suatu rantai pemasaran. Informasi tersebut terkait dengan keadaan pasar di tingkat konsumen sampai di tingkat produsen yang disalurkan ke semua pelaku usaha komoditas kacang hijau, secara otomatis akan menyebabkan ketidakstabilan harga dalam suatu proses pemasaran. Sejauh mana ketidakstabilan harga terhadap keuntungan setiap lembaga yang tergantung pada kekuatan masing- masing lembaga pemasaran.

Kondisi pasar seperti ini akan menyebabkan masalah dan merugikan petani sebagai produsen. Hal ini disebabkan petani tidak memiliki posisi tawar yang lebih tinggi, petani cenderung hanya menerima harga (price taker), sehingga peranan pedagang pengumpul lebih menonjol dengan keuntungan yang jauh lebih besar dari keuntungan yang diterima petani. Hal ini juga menyebabkan harga jual kepada konsumen menjadi lebih tinggi. Atas pertimbangan dari berbagai permasalahan tersebut, penelitian ini bertujuan untuk menganalisis elastisitas transmisi harga dan efisiensi pemasaran kacang hijau di Kabupaten Indramayu pada Tahun 2013- 2017.

\section{METODOLOGI PENELITIAN}

\section{Lokasi dan Waktu Penelitian}

Penelitian ini dilakukan sejak bulan Oktober tahun 2018 sampai dengan Agustus tahun 2019 di Kabupaten Indramayu, Jawa Barat. Lokasi dipilih secara sengaja (purposive).

\section{Metode Pengumpulan Data}

Metode penelitian ini komparatif, merupakan sejenis penelitian deskriptif yang ingin mencari jawaban secara mendasar tentang sebab akibat dengan menganalisis faktor-faktor penyebab terjadinya ataupun munculnya satu fenomena tertentu (Nazir, 2011). Desain penelitian ini adalah kasual komparatif (causal comparative research) yang ditujukan untuk menyelidiki kemungkinan hubungan sebab-akibat berdasarkan pengamatan terhadap akibat yang ada dan mencari kembali faktor yang mungkin menjadi penyebab melalui data tertentu (Nazir, 2011). Penelitian ini tidak dilakukan penarikan sampel karena menggunakan data sekunder yang bersumber pada data bulanan harga produsen dan harga konsumen kacang hijau di Kabupaten Indramayu dari bulan Januari tahun 2013 sampai dengan bulan Desember tahun 2017.

\section{HASIL DAN PEMBAHASAN}

\section{Keadaan Geografi dan Topografi}

Secara geografis Kabupaten Indramayu terletak pada $107^{\circ} 52^{\prime}-108^{\circ} 36^{\prime}$ Bujur Timur dan $6^{\circ}$ 15'- $6^{\circ} 40^{\prime}$ Lintang Selatan. Sedangkan berdasarkan topografinya sebagian besar merupakan dataran atau daerah landai dengan kemiringan tanahnya rata-rata $0-2 \%$. Keadaan ini berpengaruh terhadap drainase, bila curah hujan cukup tinggi, maka di daerah-daerah tertentu akan terjadi genangan air. Kabupaten Indramayu terletak di pesisir utara Pulau Jawa, yang melalui 11 kecamatan dengan 36 desa yang berbatasan langsung dengan laut dengan panjang garis pantai $147 \mathrm{Km}$ (Badan Pusat Statistik Kabupaten Indramayu, 2018).

\section{Iklim}

Letak Kabupaten Indramayu yang membentang sepanjang pesisir pantai utara Pulau Jawa membuat suhu udara di kabupaten ini cukup tinggi, yaitu berkisar antara $22,9^{\circ}-30^{\circ}$ Celcius. Sementara rata- rata curah hujan sepanjang Tahun 2017 adalah sebesar $1.683 \mathrm{~mm}$ dengan jumlah hari hujan 104 hari. Adapun curah hujan tertinggi terjadi di Kecamatan Patrol kurang lebih sebesar 6.792 mm dengan jumlah hari hujan tercatat 85 hari, sedang curah hujan terendah terjadi di Kecamatan Terisi kurang lebih sebesar $1.059 \mathrm{~mm}$ dengan jumlah hari hujan tercatat 79 hari (Badan Pusat Statistik Kabupaten Indramayu, 2018).

\section{Jumlah dan Laju Pertumbuhan Penduduk}


Pada akhir Tahun 2016 jumlah penduduk Kabupaten Indramayu tercatat sebanyak 1.700.815 jiwa. Sedangkan pada Tahun 2017 angka tersebut telah berubah menjadi 1.709.994 jiwa, keadaan ini menunjukkan adanya kenaikan sebesar 9.179 jiwa, dengan demikian laju pertumbuhan penduduk Kabupaten Indramayu Tahun 2016-2017 sebesar 0,54\%. Laju pertumbuhan mengalami kenaikan bila dibandingkan dengan tahun sebelumnya (Badan Pusat Statistik Kabupaten Indramayu, 2018).

\section{Pertanian}

Terdapat beberapa subsektor pertanian di Kabupaten Indramayu diantaranya adalah tanaman pangan, peternakan, perikanan dan kehutanan yang menjadi sumber mata pencaharian mayoritas penduduknya dan juga sumbangan sektor pertanian pada Produk Domestik Regional Bruto Kabupaten Indramayu.

Tanaman pangan meliputi tanaman bahan makanan, sayur-sayuran, dan buah- buahan. Tanaman bahan makanan terdiri dari jenis padi-padian, jagung, umbi- umbian, dan kacang-kacangan. Pada tanaman palawija hanya tanaman ubi kayu dan ubi jalar yang mengalami peningkatan produksi, sedangkan dari tanaman hortikultura yang mengalami kenaikan produksi adalah tanaman jambu biji, pisang, pepaya, semangka, kacang panjang dan terong (Badan Pusat Statistik Kabupaten Indramayu, 2018).

\section{Rata-rata Harga Kacang Hijau di Kabupaten Indramayu}

Rata-rata harga kacang hijau pada tingkat produsen dan konsumen di Kabupaten Indramayu pada Tahun 2013- 2017 dapat dilihat pada Gambar 1. Rata-rata harga kacang hijau di tingkat produsen cenderung meningkat setiap tahunnya, sedangkan rata-rata harga kacang hijau pada tingkat konsumen mengalami kenaikan dan penurunan setiap tahunnya.

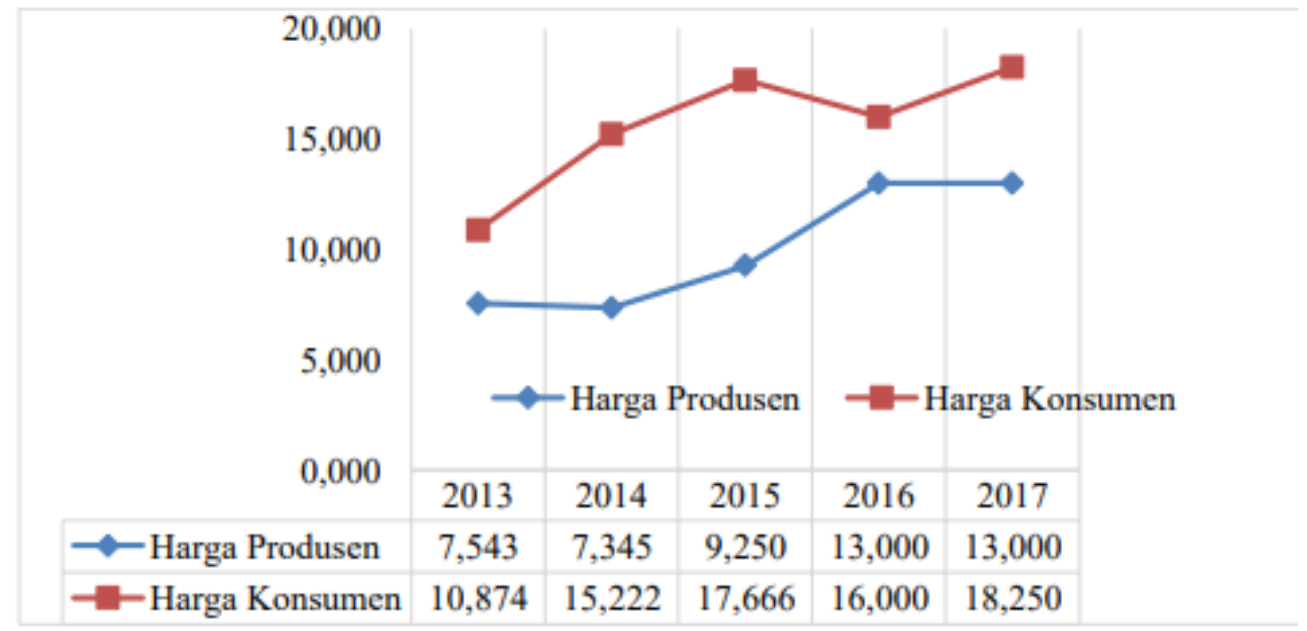

Gambar 1. Rata-rata Harga Kacang Hijau di Tingkat Produsen dan Konsumen Tahun 2013-2017

\section{Uji Asumsi Klasik}

Menurut Gujarati (2012) bahwa uji asumsi klasik adalah persyaratan statistik yang harus dipenuhi pada analisis regresi yang berbasis Ordinary Least Square (OLS), menjelaskan beberapa asumsi klasik adalah sebagai berikut :

1. Nilai rata-rata bersyarat dari unsur gangguan populasi $e_{i}$ tergantung dari nilai tertentu vafriabel menjelaskan $(\mathrm{X})$ adala 0 .

2. Variasi bersyarat dari $e_{i}$ adalah konstan atau homokedastisitas.

3. Tidak ada autokorelasi dalam gangguan

4. Variabel yang menjelaskan adalah nonstokastik (tetap dalam penyampelan berulang) atau, jika stokastik, didistribusikan secara independen dari gangguan.

5. $e$ didistribusikan secara normal dengan rata-rata data varians yang diberikan pada asumsi 1 dan 2.

Menurut Gujarati

(2012) mengemukakan dengan asumsi-asumsi tersebut, terlihat 
bahwa penaksiran kuadrat terkecil bias (OLS) dari koefisien regresi adalah penaksiran tak bisa linier terbaik (BLUE) dan dengan asumsi kenormalan didistribusikan secara normal. Berdasarkan teori di atas untuk memenuhi uji asumsi klasik, data terlebih dahulu diuji dengan analisis dalam bentuk linier menggunakan SPSS versi 20.

\section{Normalitas Data}

Uji normalitas mempunyai tujuan untuk menguji apakah dalam model regresi variabel pengganggu atau residual memiliki distribusi normal atau tidak (Gujarati, 2012). Hasil output SPSS versi 20 pada Gambar 2. Menunjukkan bahwa pola titik yang tersebar mengikuti garis diagonal maka dapat disimpulkan bahwa data berdistribusi normal. Selanjutnya untuk meyakinkan normalitas data bisa dilihat pada Gambar 3. Bentuk histogram sama dengan bentuk distribusi normal.

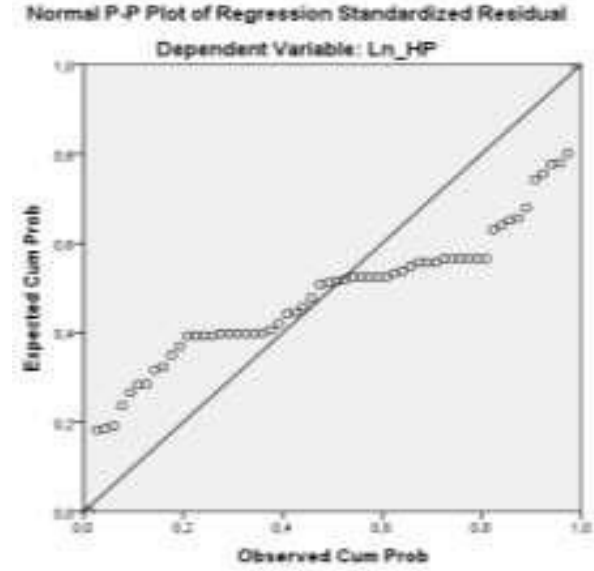

Gambar 2. Normal P-Plot of Regression Standard Residual

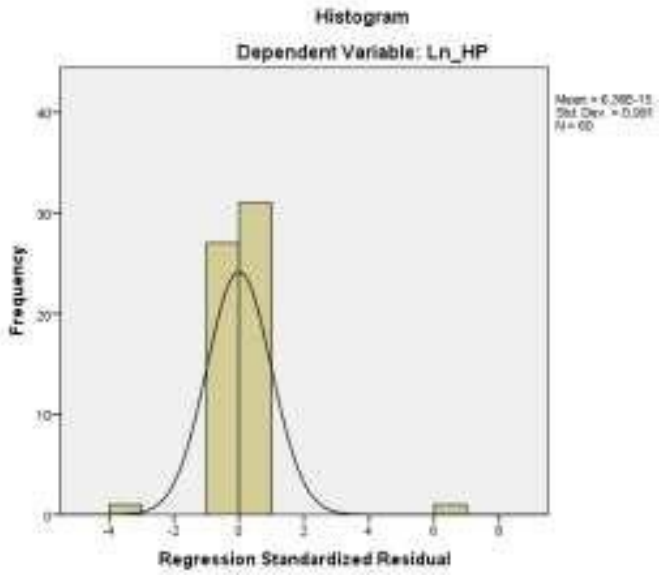

Gambar 3. Histogram

\section{Multikolinieritas}

Asumsi dalam model OLS adalah tidak adanya hubungan linier antara variabel independent, apabila terjadi hubungan maka terjadi multikolinieritas. Hubungan linier antara variabel independent dapat terjadi dalam bentuk hubungan linier yang sempurna (perfect) maupun hubungan linier yang kurang sempurna (imperfect). Apabila terjadi multikolinieritas maka masih menghasilkan estimator BLUE, tetapi menyebabkan multikolinieritas adalah dengan melihat nilai $\mathrm{R}^{2}$ dan variabel independen yang signifikan apabila $\mathrm{R}^{2}$ tinggi tetapi hanya sedikit variabel independen yang signifikan maka diduga terjadi multikolinieritas (Gujarati, 2012). Hasil output SPSS versi 20 pada Tabel 2. nilai VIF sebesar 1 dan nilai tolerance sebesar 1 yang menunjukkan bahwa tidak terdapat multikolinieritas pada data tersebut.

Tabel 2. Nilai Koefisien Regresi dan Nilai VIF Ln Harga Produsen dan Ln Harga Konsumen Kacang Hijau di Kabupaten Indramayu

\begin{tabular}{|c|c|c|c|c|c|c|c|c|c|c|}
\hline \multirow[t]{2}{*}{ Model } & \multicolumn{2}{|c|}{$\begin{array}{c}\text { Unstandardized } \\
\text { Coefficients }\end{array}$} & \multicolumn{2}{|l|}{$\begin{array}{c}\text { Standardized } \\
\text { Coefficients }\end{array}$} & \multirow[t]{2}{*}{$\mathrm{T}$} & \multirow[t]{2}{*}{ Sig. } & \multicolumn{2}{|c|}{$\begin{array}{c}95,0 \% \\
\text { Confidence } \\
\text { Interval for B }\end{array}$} & \multicolumn{2}{|c|}{ Collinearity Statistics } \\
\hline & B & Std. Error & Beta & & & & $\begin{array}{l}\text { Lower } \\
\text { Bound }\end{array}$ & $\begin{array}{l}\text { Upper } \\
\text { Bound }\end{array}$ & Tolerance & VIF \\
\hline (Constant) & 1,531 & 1,462 & & & 1,047 & ,300 & $-1,398$ & $4,46 C$ & & \\
\hline Ln_HK & ,793 & , 152 & &, 566 & $5,22 \varepsilon$ & ,000 & ,49C & 1,097 & $1,00 C$ & 1,000 \\
\hline
\end{tabular}

a. Dependent Variable: Ln_HP

\section{Autokorelasi}


Asumsi pada regresi dimana variabel dependen tidak terjadi autokorelasi dengan menggunakan Uji Durbin-Watson (DW). Uji ini menghasilkan nilai DW hitung $(d)$ dan nilai DW tabel $(d l \& d u)$. Hasil dari analisis regresi pada Tabel 2. nilai DW hitung (d) sebesar 0,120 lebih kecil dari nilai $d l$ $=1,514$ dan $d u=1,652$ yaitu menunjukkan adanya autokorelasi positif (terjadi autokorelasi). Karena $d$ sudah diketahui, gunakan teknik Theil Nagar untuk memperoleh perkiraan $\rho$ sebagai berikut :

$$
\begin{gathered}
\rho=1-\frac{d}{2} \\
\rho=1-\frac{0,120}{2} \\
\rho=0,940
\end{gathered}
$$

Setelah dilakukan perhitungan dengan rumus di atas dapat diperoleh nilai $\rho$ sebesar 0,940 . Setelah itu data sekunder yang harus di Ln akan dilakukan transformasi data dengan menggunakan taksiran sebagai berikut :

$\left(\mathrm{L}_{\mathrm{n}} \mathrm{Hp}-\rho \mathrm{L}_{\mathrm{n}} \mathrm{Hp}_{\mathrm{t}-1}\right)$ dan $\left(\mathrm{L}_{\mathrm{n}} \mathrm{Hk}-\rho \mathrm{L}_{\mathrm{n}} \mathrm{Hk}_{\mathrm{t}=1}\right)$ Caranya adalah mengurangi nilai $\rho=0,940$ kali ini dengan variabel sebelumnya dari nilai saat ini nilai pertama dari harga produsen dan harga konsumen akan ditransformasikan sebagai berikut :

$$
\sqrt{\left(1-\rho^{2}\right)} L n H p_{1} \text { dan } \sqrt{\left(1-\rho^{2}\right)} L n H k_{1}
$$

Setelah dilakukan transformasi data maka data dapat dianalisis regresi kembali dan diperoleh nilai $d$ (Durbin Watson) yang di antara nilai $d l$ dan $d u$ dan output yang sudah ditransformasikan dapat

\begin{tabular}{|c|c|c|c|c|c|c|c|c|c|}
\hline \multirow[b]{2}{*}{ Model } & \multirow[b]{2}{*}{$\mathrm{R}$} & \multirow[b]{2}{*}{$\begin{array}{c}\mathrm{R} \\
\text { Square }\end{array}$} & \multirow[b]{2}{*}{$\begin{array}{l}\text { Adjusted R } \\
\text { Square }\end{array}$} & \multirow[b]{2}{*}{$\begin{array}{l}\text { Std. Error of the } \\
\text { Estimate }\end{array}$} & \multicolumn{4}{|c|}{ Change Statistics } & \multirow{2}{*}{$\begin{array}{l}\text { Durbin- } \\
\text { Watson }\end{array}$} \\
\hline & & & & & $\begin{array}{c}\text { R } \\
\text { Square } \\
\text { Change }\end{array}$ & $\begin{array}{c}\mathrm{F} \\
\text { Change }\end{array}$ & df1 df2 & $\begin{array}{c}\text { Sig. F } \\
\text { Change }\end{array}$ & \\
\hline 1 &, $970^{\mathrm{a}}$ & ,942 & ,941 & ,07950400272 & ,942 & 936,035 & 158 &, 000 & 1,891 \\
\hline
\end{tabular}
dilihat pada Tabel 3.

Tabel 3. Nilai Koefisien Regresi Transformasi Harga Produsen dan Konsumen Kacang Hijau di Kabupaten Indramayu Tahun 2013-2017

b. Predictors: (Constant), Ln_HK

c. Dependent Variable: Ln_HP Keterangan :

$\mathrm{N}=60 ; \mathrm{K}=2 ; d l=1,514 ; d u=1,652$

Critical Values for Durbin Watson test : 5\% Significant Level

Berdasarkan hasil transformasi data di atas maka diperoleh nilai durbin Watson sebesar 1,891 dengan tingkat keyakinan adalah 95\%. Uji regresi variabel independen dan jumlah pengamatan sebanyak 60, Tabel 4. memperlihatkan nilai $d l=1,514 ; d u=1,652$. Apabila hipotesis adalah :

$\mathrm{H}_{0}: \rho=0$ (tidak ada autokorelasi positif) $\mathrm{H}_{0}: \rho \neq 0$ (ada autokorelasi positif) Maka keputusan yang tepat adalah :

$\mathrm{d}<\mathrm{dl}:$ menolak $\mathrm{H}_{0}$

$\mathrm{d}>\mathrm{du}$ : tidak menolak $\mathrm{H}_{0}$

$\mathrm{dl} \leq \mathrm{d} \leq \mathrm{du}$ : pengujian tidak meyakinkan Nilai $d$ yang diperoleh sebesar 1,891

sehingga menunjukkan bahwa tidak menolak $\mathrm{H}_{0}$ yaitu tidak terjadi autokorelasi positif. Setelah suatu data tidak terjadi autokorelasi, multikolinieritas, heteroskedastisitas, dan data berdistribusi normal. Maka dapat ditentukan data tersebut sudah dapat memenuhi asumsi klasik dan data bersifat BLUE (Best Linear Unbias Estimasi).

\section{Heterokedastisitas}

Heterokedastisitas adalah asumsi dalam regresi di mana varians dari residual tidak sama untuk suatu pengamatan ke pengamatan yang lain (Gujarati, 2012). Dasar pengambilan keputusan dalam uji heterokedastisitas dengan grafik scatterplot :

a. Jika terdapat pola tertentu pada grafik scatterplot SPSS, seperti titik-titik membentuk pola yang 
teratur (bergelombang, menyebar kemudian menyempit), maka terjadi heterokedastisitas.

b. Jika tidak terjadi pola yang jelas serta titik-titik menyebar maka tidak terjadi heterokedastisitas.

Hasil output SPSS versi 20 pada Gambar 6. yaitu gambar tersebut menyebar dan tidak membentuk pola maka data tersebut tidak terjadi Heterokedastisitas.

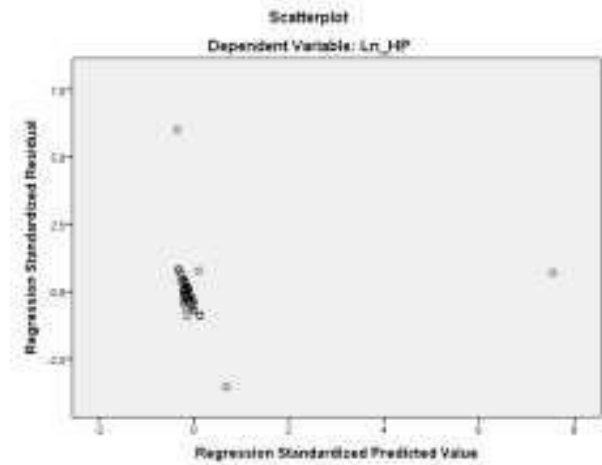

Gambar 6. Scatterplot Dependent Variabel : Ln_Hp

\section{Analisis Elastisitas Transmisi Harga}

Berdasarkan hasil analisis regresi linier sederhana, dalam proses penghitungannya menggunakan aplikasi SPSS 20 diperoleh persamaan regresi sederhana linier sebagai berikut :

$$
\mathrm{L}_{n} \mathrm{P}_{\mathrm{f}}=1,531+0,739 \mathrm{~L}_{n} \mathrm{P}_{\mathrm{r}}+\mathrm{e}
$$

Hasil analisis regresi linier sederhana yang menunjukkan terjadinya autokorelasi pada komoditas palawija tersebut nilai $D W$ (Durbin-Watson) lebih kecil dari nilai $d l$ dan $d u$ (DW < dl dan $\mathrm{du})$.

Terjadinya autokorelasi pada analisis regresi mengakibatkan penaksiran $O L S$ tidak efisien maka tindakan perbaikan harus dilakukan dengan melakukan transformasi data dengan mencari nilai $\rho$ yang didasarkan statistik $d$ (Durbin-Watson). Oleh karena itu $d$ sudah diketahui, gunakan teknik TheilNegar untuk memperoleh perkiraan $\rho$ sebagai berikut $\rho$ 1-Dari Dari semua data sekunder yang diperoleh sampel 60 .

Maka akan diperoleh persamaan sebagai berikut :

$$
\begin{gathered}
\rho=1-\frac{d}{2} \\
\rho=1-\frac{0,120}{2} \\
\rho=0,940
\end{gathered}
$$

Setelah dilakukan perhitungan dengan menggunakan rumus di atas dapat diperoleh nilai $\rho$ sebesar 0,940. Setelah itu data sekunder yang telah di Ln akan ditransformasikan terdapat pada Lampiran 5. Dengan menggunakan taksiran dapat mentransformasikan data sebagai berikut:

$\left(\operatorname{LnHp}-\rho \operatorname{LnHp}_{\mathrm{t}-1}\right)$ dan $\left(\right.$ LnHk- $\rho$ LnHp$\left._{\mathrm{t}-1}\right)$

Dengan menggunakan cara yaitu mengurangkan nilai $\rho=0,940$ kali nilai variabel sebelumnya dari nilai saat ini. Nilai pertama dari harga produsen dan harga konsumen akan ditransformasikan sebagai berikut :

$$
\sqrt{\left(1-\rho^{2}\right)} \operatorname{LnHp}_{1} \text { dan } \sqrt{\left(1-\rho^{2}\right)} \operatorname{LnHk}_{1}
$$

Setelah data ditransformasikan, dapat dilakukan analisis persamaan regresi kembali untuk menghasilkan persamaan regresi yang baik dan tidak terjadi autokorelasi antarvariabel ada pada Setelah dilakukan perhitungan dengan menggunakan rumus di atas dapat diperoleh nilai $\rho$ sebesar 0,940. Setelah itu data sekunder yang telah di Ln akan ditransformasikan terdapat pada Lampiran 5. Dengan menggunakan taksiran dapat mentransformasikan data sebagai berikut : 


$$
\mathrm{L}_{n} \mathrm{P}_{\mathrm{f}}=0,013+0,934 \mathrm{~L}_{n} \mathrm{P}_{\mathrm{r}}+\mathrm{e}
$$

Setelah dilakukan transformasi data maka diperoleh analisis regresi kacang hijau yang nilai $d$ (Durbin-Watson) yang lebih besar dari nilai $d l$ dan $d u$ yang dapat dilihat pada Lampiran 6, sehingga bisa ditarik kesimpulan bahwa tidak terjadi autokorelasi. Tabel 5 menunjukkan hasil analisis regresi dengan menggunakan Ln Harga Produsen dan Ln Harga Konsumen kacang hijau yang sudah ditransformasi data sebagai berikut.

Tabel 4. Koefisien Regresi Ln Harga Produsen dan Ln Harga Konsumen Kacang Hijau di Kabupaten Indramayu Setelah ditransformasikan.

\begin{tabular}{|c|c|c|c|c|c|c|c|c|c|}
\hline \multirow[t]{2}{*}{ Model } & \multicolumn{2}{|c|}{$\begin{array}{l}\text { Unstandardized } \\
\text { Coefficients }\end{array}$} & $\begin{array}{l}\text { Standardized } \\
\text { Coefficients }\end{array}$ & \multirow[t]{2}{*}{$\mathrm{T}$} & \multirow[t]{2}{*}{ Sig. } & \multicolumn{2}{|c|}{$\begin{array}{c}95,0 \% \\
\text { Confidence } \\
\text { Interval for B }\end{array}$} & \multicolumn{2}{|c|}{$\begin{array}{c}\text { Collinearity } \\
\text { Statistics }\end{array}$} \\
\hline & B & $\begin{array}{l}\text { Std. } \\
\text { Error }\end{array}$ & Beta & & & $\begin{array}{l}\text { Lower } \\
\text { Bound }\end{array}$ & $\begin{array}{l}\text { Upper } \\
\text { Bound }\end{array}$ & $\begin{array}{c}\text { Toleran } \\
\text { ce }\end{array}$ & VIF \\
\hline (Constant) & ,013 & ,022 & & ,614 &, 542 &,- 030 & ,057 & & \\
\hline Ln_HK & ,934 & ,031 & ,970 & 30,595 &, 000 & ,873 & ,995 & 1,000 & 1,000 \\
\hline
\end{tabular}

Dependent Variable: Ln_HP

Keterangan :

$\mathrm{N}=60 ; \mathrm{K}=2 ; d l=1,514 ; d u=1,652$

Berdasarkan hasil penelitian analisis regresi yang tidak terjadi autokorelasi, maka hasil analisis tersebut dapat disimpulkan bahwa besarnya elastisitas transmisi harga kacang hijau adalah sebesar 0,934 artinya Et $<1$ yang mengakibatkan perubahan harga sebesar $1 \%$ menunjukkan persentase penurunan harga di tingkat konsumen akan mengakibatkan perubahan harga di tingkat produsen sebesar $0,934 \%$. Nilai konstanta $\left(b_{0}\right)$ artinya setiap nilai konstanta yang dihasilkan baik nilai konstantanya negatif (-) ataupun positif (+) akan selalu mempengaruhi harga di tingkat produsen maupun konsumen. Jika nilai konstanta bernilai negatif (-) artinya harga di tingkat produsen berada di bawah nol karena tidak ada permintaan dari konsumen atau bagian harga yang diterima produsen rendah karena nilai konstanta bernilai negatif (-).Besarnya nilai koefisien determinasi $\left(R^{2}\right)$ yaitu 0,942 artinya, nilai koefisien determinasi $\left(\mathrm{R}^{2}\right)$ semakin mendekati satu, besarnya koefisien determinasi $\left(\mathrm{R}^{2}\right)$ persamaan regresi, semakin besar juga pengaruh variabel independen terhadap variabel dependen. Berdasarkan data yang sudah ditransformasikan bahwa diperoleh keputusan nilai Durbin-Watson sebesar 1,891 dengan menggunakan tingkat keyakinan sebesar 95\%, uji regresi variabel independen dan jumlah pengamatan sebanyak 60, table VIII : statistik Durbin- Watson memperlihatkan nilai-nilai $d l=1,514$ dan $d u=1,652$. Apabila hipotesisnya adalah:

$\mathrm{H}_{0}: \rho=0$ (tidak ada autokorelasi positif)

$\mathrm{H}_{\mathrm{A}}: \rho \neq 0$ (ada autokorelasi positif)

Maka keputusan yang tepat adalah :

$$
\begin{aligned}
& d>4-d_{L} \quad: \text { menolak } H_{0} \\
& d<4-d_{u} \quad: \text { tidak menolak } \\
& H_{0} 4-d_{u} \leq d \leq 4-d_{L} \quad \text { : pengujian tidak meyakinkan }
\end{aligned}
$$

Statistik $d$ hasil hitungan adalah 1,891 sehingga menunjukan bukti bahwa $d<4-d_{u}$ : tidak menolak $H_{0}$ yaitu tidak ada autokorelasi positif.

\section{Efisiensi Pemasaran Kacang Hijau}

Berdasarkan masalah yang ada dalam pemasaran kacang hijau, maka dapat diketahui bahwa 
tingkat efisiensi pemasaran kacang hijau di Kabupaten Indramayu. Analisis elastisitas transmisi harga adalah suatu persamaan untuk mengukur tingkat efisiensi pemasaran kacang hijau. Setelah dilakukan perhitungan dengan menggunakan analisis elastisitas transmisi harga dengan menggunakan analisis regresi kuadratik kemudian ditransformasikan ke dalam bentuk linier dilakukan perhitungan analisis dengan menggunakan SPSS 20, maka diperoleh hasil nilai elastisitas transmisi harga setelah ditransformasikan sebesar 0,934 maka nilai Et $<1$ artinya pemasaran kacang hijau di Kabupaten Indramayu belum efisien.

\section{KESIMPULAN DAN SARAN}

\section{Kesimpulan} berikut :

Berdasarkan hasil penelitian yang telah diuraikan maka dapat ditarik kesimpulan sebagai

1. Besarnya nilai elastisitas transmisi harga sebesar 0,934 artinya Et $<1$ artinya perubahan harga sebesar $1 \%$ menunjukkan persentase penurunan harga di tingkat konsumen akan mengakibatkan perubahan harga di tingkat produsen sebesar $0,934 \%$.

2. Pemasaran kacang hijau di Kabupaten Indramayu tidak efisien.

\section{Saran} berikut :

Berdasarkan simpulan yang telah diuraikan, maka peneliti dapat menyarankan hal-ha sebagai

1. Lemahnya kelembagaan petani menyebabkan kurangnya posisi daya tawar petani. Oleh karena itu perlu diupayakan penguatan kelembagaan petani seperti kelompok tani, koperasi dan kelembagaan yang dibentuk oleh pemerintah.

2. Untuk mencapai efisiensi pemasaran kacang hijau di Kabupaten Indramayu harus ada perhatian lebih dari pemerintah untuk memperhatikan produk pertanian dan mengupayakan tersedianya sarana informasi harga komoditas pertanian, dan kebijakan pemerintah yang mendukung penuh pembangunan pertanian.

3. Penelitian efisiensi pemasaran produk pertanian merupakan hal penting dalam mengembangkan produk pertanian dan dapat digunakan untuk membuat kebijakan pemerintah. Penelitian ini masih memiliki kekurangan dan keterbatasan oleh karena itu diupayakan adanya penelitian lanjutan.

\section{Ucapan Terimakasih}

Ucapan Terimaksih saya ucapkan kepada Fakultas Pertanian dan LPPM UNWIR yang telah membantu dalam penelitian ini sehingga penelitian dapat dijalankan.

\section{DAFTAR PUSTAKA}

Algifari. 2000. Analisis Regresi : Teori Kasus dan Solusi. BPFE UGM. Yogyakarta.

Andriani, N. N. 2015. Efisiensi Pemasaran Kacang Panjang di Kabupaten Indramayu, Skripsi. Program Studi Agribisnis, Fakultas Pertanian, Universitas Wilalodra. Indramayu.

Arifin. 2015. Pengantar Ekonomi Pertanian. Cetakan Pertaman. CV. Mujahid Press. Bandung.

Asmarantaka, R. A. 2009. Pemasaran Produk Pertanian. Bunga Rampai Agribisnis Seri Pemasaran.

Assauri, Sofjan. 2004. Manajemen Pemasaran. Rajawali Press. Jakarta.

Azzaino, Z. 1982. Pengantar Tataniaga Pertanian. Departemen Pertanian Ilmu-Ilmu Sosial Ekonomi, Fakultas Pertanian, IPB. Bogor. 
Badan Pusat Statistik Kabupaten Indramayu. 2013 - 2017. Keadaaan Harga Eceran dan Harga Produsen. Badan Pusat Statistik Kabupaten Indramayu.

Balai Penelitian Aneka Kacang dan Umbi. 2010. Teknologi Produksi Kacang Hijau. Balai Penelitian Aneka Kacang dan Umbi. Malang.

Boyd, W. L. 2000. Manajemen Pemasaran Suatu Pendekatan Strategis dengan Orientasi Global Edisi 2 Jilid 1. Erlangga. Jakarta.

Direktorat Jendral Pengolahan dan Pemasaran Hasil Pertanian 2006. Road Map Pasca Panen, Pengolahan dan Pemasaran Hasil Bawang Merah. Jakarta.

Downey, W.D., dan S. P. Erickson. 1992. Manajemen Agribisnis. Terjemahan

Rochdiat dan A. Sirait. Erlangga. Jakarta.

Ethridge, D. 1995. Reseach Methodology in Applied Economics. Iowa State University Press Ames.

Gujarati, D. N. 1978. Ekonometrika Dasar. Erlangga. Jakarata.

Gujarati, D. N. 2012. Dasar-dasar Ekonometrika, Terjemahan Mangunsong, R. C. Salemba Empat. Jakarta

Hasyim, A.I. 2012. Tataniaga Pertanian. Diktat Kuliah. Fakultas Pertanian Universitas Lampung. Lampung.

Ismet, M. 2009. Strategi dan Kebijakan Pemasaran Produk Agribisnis. Departemen Agribisnis Fakultas Ekonomi dan Manajemen IPB. Bogor.

Jumiati, E., H. D. Dwidyono, H. Slamet, dan Masyhuri. 2013. Analisis Saluran Pemasaran dan Margin Pemasaran Kelapa Dalam di Daerah Perbatasan Kalimantan Timur. Jurnal Agrifor 12(1) : 1-10.

Kohls RL, Uhl JN. 2002. Marketing of Agricultural Products. Prentice Hall. New Jersey.

Kotler, Philip. 2001. Manajemen Pemasaran : Analisis Perencanaan Implementasi dan Pengendalian. Salemba Empat. Jakarta.

Kuncoro, Mudrajat. 2011. Metode Kuantitatif: Teori dan Aplikasi untuk Bisnis dan Ekonomi. UPP STIM YKPN. Yogyakarta.

Mubyarto. 1989. Pengantar Ekonomi Pertanian. LP3ES. Yogyakarta.

Nazir, M. 2011. Metode Penelitian. PT. Galia Indonesia. Bogor.

Teguh, M. 2010. Ekonomi Industri. PT Raja Grafindo Persada. Jakarta.

Purwono dan R. Hartono. 2005. Kacang Hijau. Penebar Swadaya. Depok.

Radiosunu. 1983. Manajemen pemasaran (Suatu Pendekatan Analisis). BPPE. Yogyakarta.

Rahayu, E. S. 2009. Mereposisi Pemasaran Pertanian dalam Revitalisasi Pertanian. Makalah di sampaikan pada Sidang Senat Terbuka Universitas Negeri Surakarta pada Tanggal 10 Desember 2009. UPT Perpustakaan UNS. Surakarta. 
Rahim dan D. R. D.Hastuti. 2005. Sistem Manajemen Agribisnis. State University of Makasar Press. Makasar.

Rukmana. 1997. Kacang Hijau Budidaya dan Pasca Panen. Penerbit Kanisius. Yogyakarta.

Said, E.G. dan H. Intan. 2001. Manajemen Agribisnis. Ghalia Indonesia dengan Magister Managemen Agribisnis, Program Pasca Sarjana, Institut Pertanian Bogor. Bogor.

Santoso, T, I. 2014. Efisiensi Pemasaran Beberapa Komoditas Sayuran Penting Utama di Kabupaten Indramayu, Jurnal. Program Studi Agribisnis, Fakultas Pertanian, Universitas Wilalodra. Indramayu.

Soekartawi. 1989. Agribisnis : Teori dan Aplikasinya. Raja Garfindo Persada. Jakarta.

Soekartawi. 2002. Agribisnis : Teori dan Aplikasinya. PT Raja Garfindo. Jakarta.

Soekartawi. 2005. Agroindustri Dalam Perspektif Sosial Ekonomi. Raja Grafindo Persada. Jakarta.

Sudiyono, A. 2002. Pemasaran Pertanian. Universitas Muhammadiyah Malang. Malang.

Stanton, W. J. 2003. Prinsip Pemasaran. Cetakan Ketujuh. Jakarta : Penerbit Erlangga.

Tjiptono, F. 2001. Strategi Pemasaran. Andi Ofset. Yogyakarta.

Utomo, J.S dan S.S. Antarlina. 1998. Teknologi Pengolahan dan Produk- Produk Kacang Tunggak. Monograf Balitkabi. Malang.

Warsini. 2016. Efisiensi Pemasaran Cabai Merah di Kabupaten Indramayu. Skripsi, Program Studi Agribisnis, Fakultas Pertanian, Universitas Wilalodra. Indramayu. 